\title{
Finding the academic self: Identity development of academics as doctoral students
}

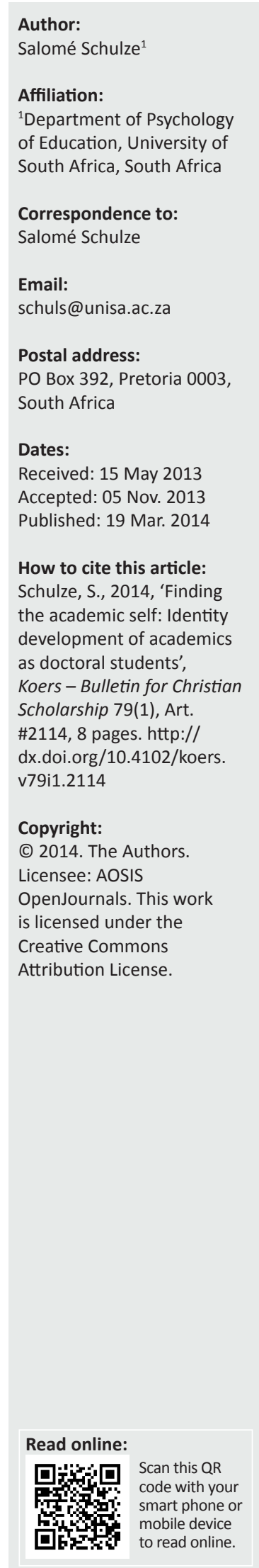

Internationally and in South Africa there is great pressure on academics to obtain doctoral qualifications. A doctorate helps to facilitate full membership of academic communities and develop academic identities. Thus, this article investigates the identity development of academics who have been enrolled for their doctoral degrees for a few years. The article is written from a postmodern perspective. The situated learning theory and symbolic interactionism were used as conceptual frameworks. By means of a narrative enquiry research approach eight interviews were conducted. Thereafter, three narratives were selected for follow-up research with the participants. From the findings, three major themes emerged with implications for universities and for postgraduate supervision. These themes are: (1) socialisation into the language and values of a stable disciplinary and/or institutional community of practice; (2) internal-external dialectic of identification (self-definition and definition of oneself offered by others) to find meaning and build self-esteem, and (3) role-taking and role-conflict.

Die vind van die akademiese self: Die identiteitsontwikkeling van akademici as doktorale studente. Internasionaal en in Suid-Afrika is daar baie druk op akademici om doktorale kwalifikasies te verwerf. 'n Doktorsgraad help om volle lidmaatskap van die akademiese gemeenskap te fasiliteer en akademiese identiteit te ontwikkel. Hierdie artikel ondersoek dus die identiteitsontwikkeling van akademici wat vir 'n paar jaar vir hul doktorsgrade geregistreer was. Die artikel is geskryf vanuit ' $n$ postmodernistiese perspektief. Gesitueerde leerteorie en simboliese interaksionisme is gebruik as konseptuele raamwerk. ' $n$ Narratiewe navorsingsbenadering is gevolg. Agt onderhoude is gevoer en daarna is drie onderhoude geselekteer vir verdere navorsing met die deelnemers. Die bevindings het drie hooftemas opgelewer met implikasies vir universiteite en nagraadse supervisie. Die temas is: (1) sosialisering in die taal en waardes van 'n stabiele dissiplinêre gemeenskap van praktiseerders; (2) interne-eksterne dialektiese identifikasie (self-definisie en definisie van die self deur ander) om betekenis te vind en selfagting te bou, en (3) rol-aanname en rolkonflik.

\section{Introduction}

Academic career development in most cases begins with a doctoral thesis (Henkel 2005:149), since the degree requires of candidates to make a significant contribution to new knowledge. This degree is therefore seen as a 'ticket' to advancement in higher education (Eddy \& Rao 2009:7). Internationally, the pressure on academics to undertake doctoral qualifications is therefore immense. In South Africa, where this study took place, this pressure is relatively new. A number of academics who have been in their jobs for years are now being pressurised to undertake a doctorate. Obtaining a doctoral degree is an important step towards obtaining membership of the higher education academic community.

Attaining full membership of the higher education academic community goes hand in hand with the development of a sound academic identity. Academic identity refers to the extent to which an individual defines themselves primarily in terms of the organisation ... or as a member of a profession' (Ibarra 1999 in Winter 2009:122). However, academic identity development is not simple. Henkel (2005) views identity as 'a deeply ambiguous concept, incorporating ideas of differences and sameness, individuation and identification, and distinctiveness and embeddedness'.

Academics have always developed legitimising academic identities through their membership of disciplines and higher education institutions (Henkel 2000; Henkel 2005). However, as the higher education landscape has changed, the notion of a 'discipline' has been replaced by the notion of a 'community of practice' (Becher \& Parry 2005:133) that includes interdisciplinary communities or extra-academic professions. These spaces of action in which academic identities are forged are global, national and local, as well as abstract and concrete. In this context, the process of identity 
formation is seen as 'finding an own voice' (Potgieter \& Smit 2009:215), or 'finding the own academic self' (Dison 2004:83), indicating a positioning of the self in the academic space. These metaphors indicate the idea of identity development as an individual project within a community.

In spite of the abovementioned importance of and pressure on academics to obtain their doctoral degrees, many of them lack this qualification. For example, at the university where this study took place, the number of academic staff without doctoral degrees was 68\% in 2011 (Council for Higher Education 2012). Ballamingie and Mikeson (2011:711) labelled this group of academics 'vulnerable' researchers who have not yet gained full membership of the academic community. Since the reputation of universities is also influenced by this issue, the university where this study took place has set itself a target to increase its number of academics with doctoral qualifications by $5 \%$ by 2015 .

Academics studying towards their doctoral degrees at the relevant university do this under somewhat challenging conditions. They have to cope with incessant discontinuity brought about by the constitution of new faculties and departments, as well as novel policies, rules and practices for teaching, that place enormous pressure on them and challenge the central meaning of identity (Robinson \& McMillan 2006:327). In order to construct their academic identities, individuals have to make choices in a complex and shifting academic landscape of communities, roles and relationships. This challenges the basic assumptions about the nature of academic identity and highlights the need to improve insight into contemporary academic identity development in higher education. The importance of such research has also been pointed out by Aitken (2010:55) and Henkel (2004:167).

Given the above, this article aims to explore how academics enrolled for their doctoral degrees forge their identities in their quest to gain full membership of the academic community. Such research could cast light on how this group may be best supervised to develop their identities as academics and as researchers, since being a competent researcher is regarded as essential to academic identity (Henkel 2005:166). To aid the investigation, two theories were found to be useful, namely Wenger's (1998) theory of learning in communities of practice, and the theory of symbolic interactionism (SI). These theories are explained below.

\section{Conceptual framework The situated learning theory}

According to the situated learning theory, two concepts are pivotal, namely community of practice and legitimate peripheral participation (Lave \& Wenger 1991). Three elements characterise a community of practice, namely the mutual engagement of its members, the negotiation of activities, and the advancement of a shared repertoire (Wenger 1998:73). Universities are made up of different communities of practice, including disciplines, and supervisor and student pairs. Each individual academic is simultaneously involved in more than one community at different levels (James n.d.:3). It is in this context that academics develop their different practices in respect of teaching and research.

Academics without doctoral degrees are, to a greater or lesser extent, legitimate peripheral participants, also called 'apprentices', in the academic or research community (Robinson \& McMillan 2006:334). As they progress with their doctoral research, their academic identities develop in accordance with how they experience themselves and the feedback they receive from significant others (Wenger 1998:149). They may proceed to more central participation in the academic community. In this way identity can be viewed as a learning trajectory that '... incorporates the past and the future in the very process of negotiating the present' (Wenger 1998:74).

A defining academic community, for example a disciplinary or research community, has various functions. Knowledge is constructed, held and transmitted by the academic community, and this keeps the community alive. It provides the language in which academics understand themselves and converse about ideas and cognitive structures with other members of that community. Such conversations may be personal or by means of engagement with published work (Dison 2004:86). Academic communities also have deeplyheld beliefs and values that are unique to them, and which are central to the development of an identity. These values relate to an obligation to others, the fulfilment of meaningfulness, and notions of respect and self-esteem (Henkel 2004:169).

\section{Symbolic interactionism and identity formation}

Symbolic interactionism is the way we learn to interpret and give meaning to the world by means of our interactions with others (Plunkett n.d.:1). The SI theory focuses on how people interact in their life-worlds through symbols such as words, rules and the roles they select and engage in.

The core principles and premises of SI focus on meaning, language and thought. As academics interact with others, meanings are formed. These academics then react to things or people on the basis of the meanings that they have assigned to them. Language is a system of symbols shared with other members of the academic community; it is the source and the vehicle of meaning. When academics use a common language, communication is possible. Language also enables inner conversations - how academics think about things. When thinking, individuals can modify their interpretation of symbols; in other words, the meanings of things or of significant others that they have come across during their lives. This interpretation will direct and shape their actions.

Roles, role-taking and role conflict are major concepts of SI. Roles are a set of beliefs that define conventional patterns of behaviour, whilst role-taking is the ability to perceive oneself in the same way as others do. If there are conflicting 
expectations about a specified role, this leads to role conflict. Such role conflict may occur when an academic is both a student and a supervisor at the same time.

Another key concept of SI is identity. Academics derive their identities from the merging of their own personal socio-cultural histories and their lived experiences. With reference to Wenger (1998), as well as to Taylor (1989) and Henkel (2005), a defining community plays an important role to form an identity. Individuals achieve a sense of identity through self-definition and definitions offered by significant others; through the language that is spoken in a community and through which values and beliefs are expressed; and through the defining spaces of each community, even though group identity is generally constructed in transactions which occur at and across boundaries (Henkel 2005:146-147). Significant experiences include the academics' or students' relationships with their supervisors, which are likely to be the most significant in forging their identities as researchers. According to Dison (2004:85), 'becoming a competent researcher is very much about developing an identity as a researcher in different contexts and disciplines'.

Different views exist on the stability of academics' identities. Taylor (1989) emphasises that although the identity may change, the possibilities for reconstruction are limited and stable identities are constructed by means of the membership of communities. In contrast, there is the postmodern, social constructionist perspective (which is also endorsed by the author of this article). This perspective rejects absolute truth and views knowledge as subjective, changeable and relative to individual cultures or worldviews (Van den Berg 2011:6). This viewpoint is criticised by some Christian scholars. Henze $(2008: 103,108)$, for example, states that the Christian believes that there are objective truths. However, a number of Christian scholars support postmodern thinking, indicating that this debate is continuing (Christian Colligation of Apologetics Debate Research \& Evangelism n.d.).

Based on the abovementioned postmodern perspective, McMullen (n.d.:4) and Henkel (2005:153) point out that the individual may have contradictory identities at the same time and that identity is continually formed and transformed. The modification of identity is the result of culturally existing meaning and the enactment of this meaning in everyday life, such as in the workplace (Smit, Fritz \& Mabalane 2012:95). The workplace, too, is not fixed, but a site of continuous change where people and practices interact in complex ways, as previously pointed out.

In line with the view that an identity incorporates the past, Collinson (2004) refers to individuals' 'biographical baggage'. This perspective indicates the usefulness of narrative enquiry in probing the identities that academics (as doctoral students) forge within their continually changing contexts, since narrative captures '... change in the whole over time' (Clandinin \& Connelly 2000:16). Thus, what follows is an explanation of how narrative enquiry was used to collect data, a presentation of the findings and a discussion of them.
The article ends with a report on the main conclusions of the study.

\section{Methodology}

In Webster's concise dictionary (in Lieblich, Tuval-Mashiach \& Zilber 1998:2), a narrative is defined as a '... discourse, or an example of it, designed to represent a connected succession of happenings'. The narratives provide the raconteurs with the opportunity to reflect on and discover their inner selves, and to reveal how they give meaning to their experiences and forge their identities.

The participants in this study were selected from a computergenerated list of academics in one faculty in the human sciences enrolled for their doctoral degrees. To collect the narrative data, eight interviews were conducted with the participants in their offices. The interviews lasted between one and one-and-a-half-hours, and were structured in three phases. In line with Rosenthal's (2003) approach, the interview commenced with this request:

Tell me your story - all the events and experiences that have been important to you in your journey up to where you are now, an academic enrolled for a doctoral degree. (n.p.)

The participants could begin wherever they wanted to. During this time, I was a silent listener who took down notes. In the second phase, I asked questions with the aim of prompting the participants to enrich the narrative content. Phase three consisted of specific questions relating to the joys and the challenges of doctoral study.

Narrative enquiries are such in-depth investigations that publications generally present only two or three stories (e.g., Smit et al. 2012). Accordingly, the eight interview transcriptions were analysed, after which three were selected for follow-up research with the participants due to their richness of information. The participants were Norma, a 49-year-old female, Vivian, a 47-year-old female, and Mike, a 51-year-old male. (To protect their anonymity, pseudonyms are used and the relevant university is referred to as University X.)

The narratives were analysed holistically to reveal the continuity of significant themes in the lives of the participants. In analysing the data, I considered three dimensions of the narratives, namely the academics' historical journeys; the meaning they attached to their feelings and views (inner focus); and their interpretation of the social interactions they had in their individual contexts (outer focus) (Clandinin \& Connelly 2000). I also cross-compared the three narratives for relevant themes. Working with the narratives in this way required a consideration of the voices of the participants, as well as of the conceptual frameworks of situated learning and SI (Lieblich et al. 1998).

Regarding the trustworthiness of the findings, Patton (2002) points out that the reliability of data in narrative research is attained by providing a credible voice that conveys 
authenticity. Connelly and Clandinin (1999) also stress the fact that the way that experiences are portrayed over time, and their adequacy and credibility, are important principles of trustworthiness.

The next section explains the findings. The findings illustrate the identity portraits of the participants and what they viewed as significant in their academic identity development. From these findings significant themes emerged with implications for universities and postgraduate supervision.

\section{Findings}

Through learning, identities are constructed (Lave \& Wenger 1991:29). Such identities are learning trajectories that include the past in dealing with the present (Wenger 1998:74). Thus, the participants learnt about their academic selves through their interaction with the significant others throughout their lives, and the feedback they received when they assumed different roles at various levels and in contexts that were diverse in terms of time, place and people (Clandinin \& Connelly 2000:32).

\section{Identity portrait: Norma}

Norma grew up in a poor farming family. From an early age she was interested in art. She excelled at school, after which she completed a degree in the arts and a teaching diploma. She taught at an art school, followed by a one-year stint as a full-time artist. At the end of that year, a residential university recruited her as an academic. She completed a master's degree in Art and obtained employment at University X. At the time of writing, she had been registered for her doctoral degree for six years.

In reflecting on her career, Norma identified school teachers as significant early influences, because they stimulated her interest in art and built her self-esteem as an artist. This facilitated her socialisation into the art community. For example, an art teacher allowed the students the freedom to express their artistic abilities in novel ways, and she profusely praised Norma's drawings when she excelled. This early stimulation of a robust art identity was strengthened by the fact that the teachers often requested Norma to design the decor and posters for high school functions, and they encouraged her to consider a career as an artist. Hence, Norma found meaning in the art community, even as a scholar. This socialisation into the art community was strengthened through visits to European art galleries after school.

Norma's socialisation into the academic art community started after matriculation when she registered for an arts degree. 'There was no other option. With my whole heart I knew this was where I belonged.' To complete the degree successfully required of Norma to set goals and to persevere in reaching these goals. This was an internalisation of the values Norma adopted from her parents. For example, her mother emphasised that Norma needed to empower herself by means of an education. 'That is why I learnt so hard and excelled academically.'

With regard to roles and role-taking, Norma consciously selected various role-models to inspire her. These role-models included, amongst others, colleagues and a supervisor. She stated:

'She [the supervisor] guided me to discover the sublime as area ... and that my art was "romantic" ... I think it is because of the farm I came from. In the town where I studied and taught as academic, I also exhibited a great deal because one of my colleagues was so productive. And, you know, you have artists whom you have never met who inspire you.'

At a later stage, Norma was appointed to a position in the Art Department at University X. Inspired by a visiting scholar, she became the driving force to have a practical doctorate in the arts institutionalised. This provided a sense of direction to her studies and enabled her to move from peripheral participation to more central participation in the community of art academics. However, as an Afrikaans-speaking academic, Norma was at first challenged by the fact that she could not converse as fluently as English-speaking academics. She had to make a conscious decision to participate actively in the international English-speaking academic community at academic workshops and conferences. As her confidence grew and her participation increased, Norma acquired the knowledge and values that are unique to art academics and which are central to the fulfilment of meaningfulness. This supported her to develop a robust academic identity.

Whilst the roles that the participants assumed at University $X$ could be enriching, these positions could also be challenging. Referring to her roles as student and lecturer, Norma stated:

'What was interesting about this journey is that I am a lecturer but I am also a student. So there is a sensitive balance that I need to maintain in that I need to keep a distance from my examiners who evaluate my exhibit, whilst also taking the lead for future doctoral supervision.'

Although the student in the supervisory relationship, Norma outgrew her supervisor in knowledge and expertise as she moved to more central participation in the academic art community. She discovered that there were not many academics in the country who could guide her well. Referring to her supervisor, she recalled:

'We are sometimes like ships passing in the night. Support is most needed when you struggle and go through the absolute darkness associated with completing a doctorate. I could not work chapter for chapter and my first attempt was repeatedly rejected. But I was stubborn, and looking back now, it had merit, but I did not have someone at my side.'

According to Norma, her submissiveness as a female was developed early in her interaction with her father. This was perpetuated in her relationship with her supervisor so that she was unable to assert herself and negotiate the practice she aimed for. She further recounted:

'I am submissive in a patriarchal relationship with a domineering male supervisor. I then say, "Alright, I will hear what you say". 
This is because of the patriarchal system that I was raised in. This caused me to be obedient instead of voicing my views. This cost me a year of getting lost in a philosophical world. Therefore, I will tell my students to stand up for what they believe in and to oppose me if they can justify their views. This is not easy because students, or females, or people of colour, often feel disempowered.'

It was only through the motivational influence of a visiting scholar whom Norma respected and selected as role-model that she could assume power in the supervisory relationship. She took the lead to get a practical thesis approved by Senate. Following this route enabled her to find her academic self and to develop into a supervisor who received several enquiries from well-known artists who respected her and were eager to pursue their doctoral degrees under her supervision.

\section{Identity portrait: Vivian}

Vivian was born in Nairobi, the youngest of eight children. Her father was a librarian at Nairobi University and her mother worked as a midwife. On finishing high school, Vivian studied for a bachelor's degree in Fine Arts. She became the head of department at a school in Nairobi, where she stayed for approximately 10 years. During this time she married. The couple immigrated to South Africa, where she completed her master's degree. She enrolled for her doctorate and was appointed as a researcher at University X. At the time of the interview, she had been registered for her doctoral degree for four years.

As with Norma, Vivian's narrative revealed how temporality connected with meaning and change or continuity in her life to have an impact on her academic identity. In her account, exposure to educational influences to socialise her into an academic career was a continuous theme. For example, her upbringing was amongst educated people, which included the fact that both her parents furthered their studies abroad. She believed that this was instrumental in determining her career as an academic. She recalled her early exposure to education and books as motivational forces that facilitated her journey towards the academe. In this regard she pointed out the particular influences of her father and her husband as follows:

'I was very close to my father. He always emphasised the value of education. He was a librarian at Nairobi University. So he would pick me up from school and I would go with him to the library. I think that impacted on my mind. When I grew up I always belonged to a library. I also married a man who loves to read and cherishes education.'

In the school landscape of values and people, Vivian was also significantly influenced in her interaction with her teachers. The teachers' voices were of great consequence because they built Vivian's self-esteem as a school student. She recollected that in high school there was one particular teacher who taught English and who took a personal interest in her:

'I formed some kind of bond with her. She made me love going to school because she gave me that extra attention. So, she had a very positive influence on what I am today.'
Regarding autonomy and self-regulation, Vivian and Norma were at opposing ends of a continuum, as illustrated by their accounts of their expectations of their supervisors. In contrast to her school days, Vivian's narrative as a doctoral student revealed a lack of self-esteem and autonomy as follows:

'I changed supervisors because I needed a supervisor who could give me hands-on supervision and mentor me....a person who guides you, meets with you on a regular basis and really takes a personal interest in you ... even beyond the work ... someone who sends you articles. With the first supervisor, when the proposal was done, I wanted him to draw a plan of meeting every week or so. [However], I would always be the one who initiated contact. I would ask: 'I am busy with chapter two, would you like to see it?' He would just tell me to finish it and then he would look at it.'

The powerful impact of gender roles was also revealed by Vivian's account of her academic career. In her interaction with her husband, she could only focus on her doctoral research when work took him away from home. Whenever he was home she assumed the role of a submissive female who served his meals and played hostess to his visitors. She thus once again assumed a powerless role, with implications for her academic identity development.

\section{Identity portrait: Mike}

Mike was the third of seven children and the only one in his family to complete secondary school. He grew up under difficult circumstances. His father died when he was very young and his mother remarried, a marriage that was marked by alcoholism and domestic violence. However, Mike matriculated, and was appointed at University $X$, where he eventually completed his master's degree. At the time of writing he had been registered for his doctoral degree for six years.

Mike's journey to find his academic self was vastly different from those of the other two participants. His narrative revealed the process of the change he underwent from schoolboy to academic. Because of his alcoholic, abusive parents he had a desperate need 'to be something or someone'. Thus, a continuous theme in his quest to find his academic self was that of the need for emotional support and of significant others who recognised his efforts and provided him with positive feedback. In the context of his family, significant interactions included an elderly relative. Mike recalled:

'The sister of my grandfather made me feel that I was the best thing since sliced bread. She did not motivate me academically, but the mothering and the love and support she gave me, and the fact that she made me feel important, influenced me.'

In the school landscape of people and values, Mike recalled how the school principal, who was also a teacher, gave him a lot of attention, and became a role-model. Since Mike could read very well, the teacher made a fuss of him, and thus enhanced his self-esteem. Mike related:

'This was the first time that someone [had] acknowledged me. This man had a significant influence on my life ... he made me feel important. If I achieved poorly in a test, he would say: "You 
did well, but when we write again I want you to show me you can obtain full marks". This played a big role in my life.'

Other professionals were also significant in providing pastoral care - giving Mike emotional support, and acting as mentors and role-models. Examples included professionals such as a psychologist who supported him emotionally and a poet who facilitated his academic development through the stimulating discussions they had and by acting as his mentor. In his accounts, Mike also recalled his interaction with other creative people who exposed him to the arts and thus motivated him to further his studies. This facilitated his socialisation into the disciplinary academic community.

Similarly to Vivian, Mike also changed supervisors, in particular for emotional reasons. Whilst the first supervisor was relatively unavailable, and readily dished out 'destructive' criticism, he experienced his new female supervisor as 'motherly and emotionally supportive'. She provided constructive criticism that built his self-esteem, which allowed him to move to more central participation in the academic community.

The abovementioned findings reveal continuity in the themes that were significant in the lives of the participating academics. These themes are illuminated next, and their implications for universities and for supervision are pointed out.

\section{Discussion}

An analysis of the identity portraits of the participants revealed three common themes that may resonate with other academics outside of this investigation who are also postgraduate students. These themes give direction to how academics as students could best be supervised to complete their degrees and develop their academic identities.

The first theme is that of socialisation into the language and values of a stable community of practice. Henkel (2004:167) has found that the strength and stability of academic identities is strongly associated with membership of communities, and James (n.d.:12) points out that sustaining membership in an academic community is dependent upon participating in its activities. Such participation allows conversation about ideas and cognitive structures with other members of the community and facilitates the adoption of relevant values.

The narratives of Norma and Vivian suggested that they were at opposing ends of a continuum with regard to their socialisation in their different communities, and hence also in the strength of their academic identities. Norma adopted the values of the community of practical artists and assumed a leadership role to have such a doctorate institutionalised. She thus made a significant contribution to the art community. As an Afrikaans-speaking academic, she also consciously overcame her hesitation to participate actively in academic discussions in public forums.
Vivian's narrative contrasts with that of Norma. She was socialised into the world of books and education at a young age and this built her identity as a scholar. Yet, as an academic at University $X$, without any active participation in the practices of her community, this identity was transformed and seemed fragile.

A second theme that could be identified is that of an internal-external dialectic of identification (self-definition and definition of oneself offered by others) to find meaning and build self-esteem. There is a reciprocal relationship between positive self-esteem and affirmative feedback from significant others (Dison 2004:95). Norma's academic identity was developed in spite of her doctoral supervisor, through the respect of a visiting scholar and professional artists who shared her values. Mike too, was motivated and inspired by the positive definitions of him offered by teachers, a family member, professionals and a supervisor who proffered pastoral care in accordance with a Christian philosophy. Vivian's apparent lack of self-esteem and need for constant support motivated her to change supervisors to one who was more in touch with her needs.

A third theme that surfaced is that of role-taking and role conflict, for example with regard to gender roles. The roles that the participants selected influenced their choices and their behaviour, and thus shaped their identities. Norma's narrative revealed how she selected roles that were in conflict in that they empowered as well as disempowered her. As often happens at the beginning of supervisory relationships (Dison 2004:94), Norma assumed a submissive, powerless role in her relationship with her doctoral supervisor. This had a constraining effect on her studies and identity development. Several other authors have confirmed the significant influence of power issues in supervision (Manathunga 2007:210; Schulze 2012; Storm, Todd, Sprenkle \& Morgan 2001:235). Later in the relationship, when Norma assumed agency and power she played a leadership role in the academic community, strengthening her own academic identity in this way. Conti, Hewson and Isken (2001:166) emphasise that academics being supervised now need to be empowered to claim their voice, be active agents during their doctoral studies and assume accountability for the process and the product of the research.

The ability to assume power is influenced by self-esteem. Positive self-esteem facilitates self-regulation, which is an important aspect of professional competency and identity (Dison 2004:93). Through self-regulation students 'activate and sustain their thoughts, behaviours and emotions to reach their goals' (Zimmerman, in Sungur \& Tekkaya 2006:307).

Vivian's narrative illustrated how she assumed a passive and powerless role in her relationship with her supervisor, which kept her a peripheral participant in the academic community (Dison 2004:97). The inability to assume power, and therefore the excessive need in some students for assistance, as shown by Vivian, was also found with international students in Australia (Cadman \& Ha 2001:224; Dietz, Jansen \& Wadee 
2006:74; Manathunga 2007). It indicated the quandary of supervisor-student pairings where the participants were in conflict with the adopted supervisory style (Mainhard, Van der Rijst, Van Tartwijk \& Wubbels 2009:360).

\section{Conclusion}

In order to develop a robust academic identity, it is important to be accepted into the academic community. There are several indicators of such acceptance, which include the successful approval of postgraduate proposals of students at Senate, the acceptance of articles for publication, being invited to participate at academic forums and obtaining a doctoral degree. Obtaining the degree is the first step towards many individuals' development as academics because it indicates that the individual was able to contribute new knowledge to a selected field, thus 'proving' scholarship. The aim of this article was therefore to understand what academics enrolled for their doctorates saw as significant in their personal trajectories to complete their degrees and develop their academic identities. To this end, three academics' narratives were analysed. Aspects of these narratives may resonate with other academics outside of this investigation who are also postgraduate students.

The identified themes indicate areas to target in order to guide academics to complete their degrees successfully and may stimulate reflection and debate on what constitutes best practices. This research has revealed that more reflection is needed on the process rather than on the product of supervision. From the narratives, three major themes emerged with implications for practice: (1) academics or students need to participate regularly and actively in the practices of a stable community of practice and thus be socialised into the language and values of that community. For academics who are not English first language speakers this is often a challenge; (2) supervisors need to take cognisance of the quality of the self-definitions they offer those whom they supervise. These definitions can enable or disable those who are supervised to find meaning and build self-esteem. Pastoral care, a key principle of Christianity, is important and highlights the human side of supervision; (3) more supervisor reflection on supervisory style and on empowering or disempowering roles is also needed. Not all academics, as students, value autonomy. Some doctoral students desire excessive support, perhaps because of a lack of positive self-esteem. How this issue could be resolved may well be the focus of follow-up research.

Many academics will benefit from further mentoring and participation in the community of practice after obtaining their doctoral degrees. This guidance can be given by a full professor who is an expert in the field of specialisation. However, a doctorate is a first, important step to acquiring full membership in the academic community. Although the above-mentioned findings and recommendations may seem self-evident, the storied accounts revealed gaps between assumptions that appear in the literature and current practices. It is hoped that this article may make a contribution to improving supervisory practices and better guiding novice academics to find their academic selves.

\section{Acknowledgements Competing interests}

The author declares that she has no financial or personal relationship(s) that may have inappropriately influenced her in writing this article.

\section{References}

Aitken, A., 2010, 'Becoming an academic: Professional identity on the road to tenure', Journal of Educational Thought 44(1), 55-68.

Ballamingie, P. \& Mikeson, S., 2011, 'The vulnerable researcher: Some unanticipated challenges of doctoral fieldwork', The Qualitative Report 16(3), 711-729.

Becher, T. \& Parry S., 2005, 'The endurance of the disciplines', in I. Bleiklie \& M. Henkel (eds.), Governing knowledge: A study of continuity and change in higher education, pp. 133-144, Springer, Dordrecht. http://dx.doi.org/10.1007/1-4020education,

Cadman, K. \& Ha, H.T., 2001, “'Only connect”: Transactional supervision as the "rainbow bridge"', in A. Bartlett \& G. Mercer (eds.), Postgraduate research supervision: Transforming (r)elations, pp. 215-222, Peter Lang, New York.

Christian Colligation of Apologetics Debate Research \& Evangelism n.d, Christianity and postmodernism, viewed 31 January 2012, from http://christiancadre.org/ topics/postmodern.html

Clandinin, D.J. \& Connelly, F.M., 2000, Narrative inquiry. Experience and story in qualitative research, Jossey-Bass Publishers, San Francisco. PMCid:PMC2583024

Collinson, J.A., 2004, 'Occupational identity on the edge: Social science contract researchers in higher education', Sociology 38(2), 313-329. http://dx.doi. org/10.1177/0038038504040866

Connelly, F.M. \& Clandinin, D.J., 1999, 'Narrative inquiry' in J.P. Keeves \& G. Lamoski (eds.), Issues in educational research, pp. 132-140, Pergamon, Amsterdam.

Conti, J., Hewson, D. \& Isken, J., 2001, 'Power, voice and connection', in A. Bartlett \& $\mathrm{G}$. Mercer (eds.), Postgraduate research supervision: Transforming (r)elations, pp. 161-174, Peter Lang, New York. PMid:11514066

Council for Higher Education, 2012, South African higher education performance data 2000-2010: Academic staff with doctorates, viewed 19 September 2012, from http://www.che.ac.za/

Dietz, A.J., Jansen, J.D. \& Wadee, A.A., 2006, Effective Ph.D. supervision and mentorship, Rozenberg, Amsterdam.

Dison, A., 2004, "'Finding her own academic self": Research capacity development and identity formation', Perspectives in Education 22(4), 83-98.

Eddy, P. \& Rao, M., 2009, 'Leadership development in higher education programs', The Community College Enterprise 7(26), 7-26.

Henkel, M., 2000, Academic identities and policy change in higher education, Jessica Kingsley, London.

Henkel, M., 2004, 'Current science policies and their implications for the formation and maintenance of academic identity', Higher Education Policy 17, 167-182. $\mathrm{http}: / / \mathrm{dx}$.doi.org/10.1057/palgrave.hep.8300049

Henkel, M., 2005, 'Academic identity and autonomy revisited', in I. Bleiklie \& M. Henkel (eds.), Governing knowledge: A study of continuity and change in higher education, pp. 145-165, Springer, Dordrecht. http://dx.doi.org/10.1007/1-40203504-7_10

Henze, M.E., 2008, 'Demystifying "constructivism": Teaching unnecessary baggage from useful pedagogy', Christian Education Journal 6(1), 87-111.

James, N., n.d., 'Academic identity development: Narratives of shifting experiences', in The British Sociological Association, viewed 16 April 2012, from http://www. britsoc.co.uk/user_doc/05BSAConfJamesNalita.pdf

Lave, J. \& Wenger, E., 1991, Situated learning: Legitimate peripheral participation, Cambridge University Press, Cambridge. http://dx.doi. org/10.1017/ CBO9780511815355

Lieblich, A., Tuval-Mashiach, R. \& Zilber, T., 1998, Narrative research. Reading, analysis, and interpretation, Sage Publications, Thousand Oaks.

Mainhard, T., Van der Rijst, R., Van Tartwijk, J. \& Wubbels, T., 2009, 'A model for the supervisor-doctoral student relationship', Higher Education 58, 359-373. http:// supervisor-doctoral student relationship',
dx.doi.org/10.1007/s10734-009-9199-8

Manathunga, C., 2007, 'Supervision as mentoring: The role of power and boundary crossing', Studies in Continuing Education 29(2), 207-221. http://dx.doi. org/10.1080/01580370701424650

McMullen, C., n.d., 'Taking a close look at award-winning university teachers: A narrative study of developing expertise in times of change', in Lancaster University, viewed 05 January 2012, from http://www.lancaster.ac.uk/

Patton, M.Q., 2002, Qualitative research and evaluation methods, 3rd edn., Sage Publications, Thousand Oaks.

Plunkett, S., n.d., 'Symbolic interactionism theory', in csun.edu, viewed 28 March 2012, from http://www.csun.edu/ 
Potgieter, F. \& Smit, B., 2009, 'Finding academic voice. A critical narrative of knowledge-making and discovery', Qualitative Inquiry 15(1), 214-228. http:// knowledge-making and discovery', Qualita
dx.doi.org/10.1177/1077800408322792

Robinson, M. \& McMillan, W., 2006, 'Who teaches the teachers? Identity, discourse and policy in teacher education', Teacher and Teacher Education 22, 327-336. http://dx.doi.org/10.1016/j.tate.2005.11.003

Rosenthal, G., 2003, 'The healing effects of storytelling: On conditions of curative storytelling in the context of research and counselling', Qualitative Inquiry 9(6), 915-933. http://dx.doi.org/10.1177/1077800403254888

Schulze, S., 2012, 'Empowering and disempowering students in student-supervisor relationships', Koers - Bulletin for Christian Scholarship 77(2), 1-8. http://dx.doi. org/10.4102/koers.v77i2.47

Smit, B., Fritz, F. \& Mabalane, V., 2012, 'A conversation of teachers: In search of professional identity', The Australian Educational Researcher 37(2), 93-106. http://dx.doi.org/10.1007/BF03216924
Storm, C.L., Todd, T.C., Sprenkle, D.H. \& Morgan, M.M., 2001, 'Gaps between MFT supervision assumptions and common practice: Suggested best practices', Journal of Marital and Family Therapy 27(2), 227-239. http://dx.doi.org/10.1111/j.17520606.2001.tb01159.x, PMid:11314555

Sungur, S. \& Tekkaya, C., 2006, 'Effects of problem-based learning and traditional instruction on self-regulated learning', The Journal of Educational Research 99(5), 307-317. http://dx.doi.org/10.3200/JOER.99.5.307-320

Taylor, C., 1989, Sources of the self: The making of modern identity, Cambridge University Press, Cambridge.

Van den Berg, M.E.S., 2011, 'Conceptual foundations for critical reasoning and learner engagement in ODL', Progressio 33(1), 63-79.

Wenger, E., 1998, Communities of practice: Learning, meaning, and identity, Cambridge University Press, New York. http://dx.doi.org/10.1017/CBO9780511803932

Winter, R., 2009, 'Academic manager or managed academic? Academic identity schisms in higher education', Journal of Higher Education Policy and Management schisms in higher education', Journal of Higher Education Policy a
31(2), 121-131. http://dx.doi.org/10.1080/13600800902825835 